\title{
Increased growth hormone (GH), growth hormone receptor (GHR), and insulin-like growth factor I (IGF-I) gene transcription after hyperosmotic stress in the Brazilian flounder Paralichthys orbignyanus
}

\author{
Karina M. Meier · Márcio A. Figueiredo $\cdot$ Michel T. Kamimura • \\ Jomar Laurino · Rodrigo Maggioni · Luciano S. Pinto • Odir A. Dellagostin • \\ Marcelo B. Tesser · Luís A. Sampaio · Luis F. Marins
}

Received: 31 May 2008/Accepted: 26 October 2008/Published online: 11 December 2008

(C) Springer Science+Business Media B.V. 2008

\begin{abstract}
Growth hormone (GH) action is the result of an intracellular cascade initiated just after its interaction with the growth hormone receptor (GHR) located on the surface of target cells. This cascade culminates with the transcription of target genes, such as the insulin-like growth factors (IGFs), which are responsible for most $\mathrm{GH}$ biological effects. In
\end{abstract}

K. M. Meier - M. A. Figueiredo - M. T. Kamimura .

L. F. Marins $(\varangle)$

Instituto de Ciências Biológicas, Universidade Federal do Rio Grande-FURG, Rio Grande, RS, Brazil

e-mail: dqmluf@furg.br

\section{J. Laurino}

Faculdade de Biociências, Centro de Biologia Genômica e Molecular, Pontifícia Universidade Católica do Rio

Grande do Sul, Porto Alegre, RS, Brazil

R. Maggioni

Faculdade de Educação Ciências e Letras do Sertão Central, Universidade Estadual do Ceará, Quixada, CE, Brazil

\section{Present Address:}

R. Maggioni

School of Forensic and Investigative Science, University of Central Lancashire, Preston PR1 2HE, UK

\section{S. Pinto · O. A. Dellagostin}

Centro de Biotecnologia, Universidade Federal de Pelotas, RS, Pelotas, Brazil

M. B. Tesser · L. A. Sampaio

Instituto de Oceanografia, Universidade Federal do Rio Grande-FURG, Rio Grande, RS, Brazil addition to its central role in growth, fish $\mathrm{GH}$ is also involved with osmoregulatory control. Within this context, the objective of the present work was to isolate GH, GHR, and IGF-I cDNAs from the Brazilian flounder Paralichthys orbignyanus and evaluate whether these genes are induced by hyperosmotic stress. The obtained results indicated that $\mathrm{GH}$ mRNA had a significant peak only $24 \mathrm{~h}$ after hyperosmotic stress. In gills, GHR mRNA was significantly increased after 7 days. In liver, GHR and IGF-I mRNAs were significantly increased in $72 \mathrm{~h}$ and both reached even higher levels after 7 days. These results indicate that hyperosmotic stress can increase GH sensitivity in the gills and liver of $P$. orbignyanus and, consequently, improve IGF-I production. The management of this parameter could be useful in achieving better growth performance for this and other commercially important species in which GH has a direct correlation with osmoregulatory mechanisms.

Keywords Hyperosmotic stress .

Growth · Osmoregulation ·

Semi-quantitative RT-PCR

\section{Introduction}

Growth is the result of complex molecular interactions in which growth hormone $(\mathrm{GH})$ plays a major role in 
all vertebrates. At the tissular level, the pleiotropic effects of GH result from its interaction with the growth hormone receptor (GHR) located on the surface of target cells. GHR is a membrane protein which links to GH with high affinity and specificity, activating a post-receptor signaling system which culminates in activating the transcription of target genes, such as the insulin-like growth factor I, IGF-I (Kopchick and Andry 2000; Takeda and Akira 2000).

Several studies carried out in salmonid fishes have shown that the GH/IGF-I axis is also involved in osmoregulation, increasing salinity tolerance through its stimulation of the chloride cell number and the activity of $\mathrm{Na}^{+}, \mathrm{K}^{+}$-ATPase enzyme in gills (Bolton et al. 1987; Sakamoto and Hirano 1993; Madsen et al. 1995; McCormick 1996). Since changes in water salinity during critical life-history stages can alter levels of GH and correlated hormones like IGF-I, the control of this parameter could be used to maximize growth and development in economically important teleosts. However, in non-salmonid teleosts, the osmoregulatory role of this axis is less clear and only a few species have been studied on this subject, with controversial results being reported. Pituitary GH cell numbers and plasma GH levels seem to depend on the species studied and the environmental salinity (Mancera and McCormick 1998).

The Brazilian flounder Paralichthys orbignyanus (Valenciennes 1839) is found from Rio de Janeiro (Brazil) to Mar del Plata (Argentina) (Figueiredo and Menezes 2000). This species inhabits estuaries and coastal waters and it is commonly subjected to brackish water, especially during its growth period. Brazilian flounder is euryhaline; newly metamorphosed juveniles tolerate freshwater and full-strength seawater (Sampaio et al. 2007). According to Silveira et al. (1995), males mature at $26.3 \mathrm{~cm}$, while females mature at $37.4 \mathrm{~cm}$.

On the Brazilian coast, P. orbignyanus is exploited by both artisanal and commercial fisheries. It is a species with great potential for aquaculture not only for its high commercial value, but also because of its euryhalinity (Wasielesky et al. 1995), tolerance to high concentrations of nitrogenous compounds (Bianchini et al. 1996) and acid stress (Wasielesky et al. 1997). Sampaio et al. (2001) reported that the best growth rate achieved by $P$. orbignyanus is still lower than those observed for turbot and Japanese flounder in commercial aquaculture.
Since osmoregulation is an energy-demanding process, isosmotic salinities minimize osmoregulatory stress and should increase the energy available for growth and/or survival (Sampaio and Bianchini 2002). Nevertheless, GH levels can be increased by hyperosmotic stress, resulting in higher growth rates in fish, since this hormone enhances somatic growth by stimulating protein synthesis, improving feed conversion, and increasing appetite in many species (Björnsson 1997; Pérez-Sánchez and Le Bail 1999). Within this context, the objective of the present work was to analyze the expression of $\mathrm{GH}$ in the pituitary and GHR/IGF in the gills and liver of P. orbignyanus after hyperosmotic stress, in order to evaluate whether salinity can induce the transcription of genes related to the somatotrophic axis.

\section{Materials and methods}

The fish used in this study (18-26 cm; 70-220 g) were originated from artificial spawning at Estação Marinha de Aquacultura (EMA-FURG, Brazil). Individuals were acclimated for one week to the salinity of $11 \mathrm{~g} \mathrm{l}^{-1}$, the species isosmotic point (Sampaio and Bianchini 2002). After acclimation, one group of fish was transferred to a tank with sea water at $30 \mathrm{~g} \mathrm{l}^{-1}$, while another group was kept at $11 \mathrm{~g}^{-1}$. The water temperature in both tanks was $24^{\circ} \mathrm{C}\left( \pm 2^{\circ} \mathrm{C}\right)$, the water renewal rate was $100 \%$ per day, and constant aeration was provided. The photoperiod was set at 12 / $12 \mathrm{~h}$ daylight/darkness. The fish were fed ad libitum with chopped fish once a day. They were anesthetized with benzocaine $\left(50 \mathrm{mg} \mathrm{l}^{-1}\right)$ before pituitary, gill, and liver sampling. They were sampled on four occasions: 3, 24, $72 \mathrm{~h}$, and 7 days after transfer.

Total RNA was extracted immediately after tissue sampling with TRIzol reagent (Invitrogen, Brazil), following the recommended protocol. Pituitaries from three individuals were grouped and three pituitary pools were analyzed per sampling time and salinity. For gills and livers, three individuals from each of the two salinities were drawn each time. cDNA synthesis was conducted through reverse transcriptase-polymerase chain reaction (RT-PCR) using RT SuperScript ${ }^{\mathrm{TM}}$ III enzyme (Invitrogen, Brazil), according to the manufacturer's protocol.

In order to isolate and to sequence $P$. orbignyanus GH, GHR, and IGF-I cDNAs, homologous or 
degenerate primers were designed over conserved gene regions, as found through the CLUSTAL_X (Thompson et al. 1997) alignment of sequences from other fish species, available at GenBank (http:// www.ncbi.nlm.nih.gov). The primers used for gene isolation are shown in Table 1. The PCR conditions were as follows: denaturing cycle of $94^{\circ} \mathrm{C} / 2 \mathrm{~min}$, followed by 35 cycles of $94^{\circ} \mathrm{C} / 30 \mathrm{~s}, 50^{\circ} \mathrm{C} / 1 \mathrm{~min}$, $72^{\circ} \mathrm{C} / 1 \mathrm{~min}$, followed by a final elongation step of $72^{\circ} \mathrm{C} / 15 \mathrm{~min}$. The only exception was for the IFG-I gene, in which the primer's annealing conditions were $63^{\circ} \mathrm{C} / 30 \mathrm{~s}$. PCR products were visualized on $1 \%$ agarose gel electrophoresis containing $0.5 \mu \mathrm{g} \mathrm{ml}^{-1}$ ethidium bromide on a UV transilluminator. Bands corresponding to the expected product size were excised from the gel and the amplicon was purified through CONCERT ${ }^{\mathrm{TM}}$ Rapid Gel Extraction System (Invitrogen, Brazil). Purified product for $\mathrm{GH}$ and GHR were cloned employing the TOPO ${ }^{\circledR}$ TA Cloning kit (Invitrogen, Brazil) and plasmids of overnight cultures of bacterial colonies were extracted with CONCERT $^{\mathrm{TM}}$ Rapid Plasmid Purification Systems (Invitrogen, Brazil). Plasmids were analyzed by restriction enzyme digestion (EcoR I, Invitrogen, Brazil) to confirm the size of the inserted cDNA. Automated sequencing was performed using M13 universal primers and the BigDye Ready Reaction Mix (Applied Biosystems) according protocol by the manufacturer. For IGF-I and $\beta$-actin, the purified PCR products were directly sequenced. Nucleotide sequences and translated amino acid sequences were compared to the GenBank database through the BLASTP on-line tool (Altschul et al. 1997). After the sequences were confirmed, internal gene-specific primers were designed for gene expression analysis (Table 1).

Gene expression analysis was conducted through semi-quantitative RT-PCR, using a denaturing cycle of $94^{\circ} \mathrm{C} / 2 \mathrm{~min}$, followed by $94^{\circ} \mathrm{C} / 30 \mathrm{~s}, 60^{\circ} \mathrm{C} / 1 \mathrm{~min}$, $72^{\circ} \mathrm{C} / 1 \mathrm{~min}$, followed by a final elongation step of $72^{\circ} \mathrm{C} / 10 \mathrm{~min}$. For all of the genes analyzed, a number of previous trial runs were carried out in order to determine the number of cycles which would be enough to produce detectable amplification, while remaining within the linear PCR amplification limits. For GH, 22 cycles were used, while for GHR, IGF-I, and $\beta$-actin, 35 cycles were needed. $\beta$-actin was used as an internal control for data normalization (Chelly et al. 1988), since previous tests showed no variation between the treatments used (11 and $30 \mathrm{~g} \mathrm{l}^{-1}$ ). PCR products were electrophoresed on $1.5 \%$ agarose gel containing $0.5 \mu \mathrm{g} \mathrm{ml}^{-1}$ ethidium bromide.
Table 1 Primers used for the isolation and expression analysis of growth hormone $(\mathrm{GH})$, growth hormone receptor (GHR), insulin-like growth factor I (IGF-I), and $\beta$-actin genes of

Paralichthys orbignyanus

\begin{tabular}{|c|c|c|}
\hline Genes & Primers & $\begin{array}{l}\text { PCR product } \\
\text { size }(\mathrm{bp})\end{array}$ \\
\hline \multicolumn{3}{|c|}{ Homologous } \\
\hline GH & $\begin{array}{l}\text { EXO1: 5'-CCCAGACCAGCCATGGACAGA-3' } \\
\text { AUAP: 5'-GGCCACGCGTCGACTAGTAC-3' }\end{array}$ & 747 \\
\hline GHR & $\begin{array}{l}\text { GHR }_{12} \text {-FOR: } 5^{\prime} \text {-CGACGACTCCTGGGTTGARTTYGTHGA-3' } \\
\text { GHR }_{13} \text {-REV: } 5^{\prime} \text {-TGTCGGACACCTGGGCRTARAARTC-3' }\end{array}$ & 374 \\
\hline IGF-I & $\begin{array}{l}\text { fIGFI-FOR: 5'-GCCACACCCTCTCACTACTGCT-3' } \\
\text { fIGFI-REV: 5'-GCTGTGCTGTCCTACGCTCTG-3' }\end{array}$ & 363 \\
\hline$\beta$-actin & $\begin{array}{l}\text { BAC-FOR: 5'-ACHAACTGGGAYGAYATGG-3' } \\
\text { BAC-REV: 5'-TAGATGGGBACDGTGTGGG-3' }\end{array}$ & 258 \\
\hline \multicolumn{3}{|c|}{ Gene-specific } \\
\hline GH & $\begin{array}{l}\text { GH-FOR: } 5^{\prime} \text {-GTTCAGTATCTTCACCTGGTTGC-3' } \\
\text { GH-REV: 5'-TGCAGTTAGCTTCTGGAAAGAGT-3' }\end{array}$ & 466 \\
\hline GHR & $\begin{array}{l}\text { GHR-FOR: 5'-ACTCCTGGGTTGAATTCGTAGAG-3' } \\
\text { GHR-REV: 5'-CCATCTTCAGTATCAAAGGATGC-3' }\end{array}$ & 283 \\
\hline IGF-I & $\begin{array}{l}\text { IGFI-FOR: 5'-TCTCACTACTGCTGTGTGTCCTC-3' } \\
\text { IGFI-REV: 5'-GTACTAACCTTGGGTGCTCTCG-3' }\end{array}$ & 310 \\
\hline$\beta$-actin & $\begin{array}{l}\beta \text { ACT-FOR: 5'-AAGATCTGGCATCACACCTTCTA-3' } \\
\beta \text { ACT-REV: 5'-GGAGTCCATGACGATACCAGTG-3' }\end{array}$ & 216 \\
\hline
\end{tabular}


For each gene analyzed, all individuals from the two treatments were run in the same gel for comparison. Digitalized images of the gels were analyzed employing the software 1DScan (Scanalytics).

The data were analyzed through analysis of variance (two-way ANOVA), employing Tukey's test. Normality and variance homogeneity were previously verified and a significance level of 5\% was adopted in every case. All statistical tests employed fixed type I error in 5\% $(\alpha=0.05)$.

\section{Results}

The $P$. orbignyanus GH cDNA (GenBank accession no. DQ112550) showed a 573 nucleotide coding region, followed by a 147 nucleotide $3^{\prime}$ UTR, which includes a polyadenylation site (AATAAA). The entire GH coding region was obtained and can be coherently translated in a 190 amino acid chain, from which the N-terminal first 17 amino acids are highly hydrophobic. These first 17 amino acids also present high sequence homology to other flounder $\mathrm{GH}$ signaling peptides (94\%), and are, therefore, very likely to constitute $P$. orbignyanus signaling peptide. The remaining 173 amino acid chain presents typical fish GH features, such as the presence of four cysteines in conserved regions, which allow the formation of the two characteristic disulfide bridges essential to the molecule tertiary structure. In addition, only one tryptophan is present and various portions of the amino acid sequence are highly conserved in relation to many known fish GHs (homology of $97 \%$ with Paralichthys lethostigma; Table 2). There is only one potential glycosilation site at $\mathrm{Asn}^{186}$, formed by the sequence Asn-Cys-Thr. The mature form of the hormone initiates with a glutamine.
For GHR, IGF-I, and $\beta$-actin cDNAs, only partial coding sequences were obtained (GenBank acession nos. DQ112551, EU542579, and EU542580, respectively). The identities of the obtained nucleotide and amino acid sequences are shown in Table 2. All sequences were very similar to other flounder sequences, ranging from 76 to $98 \%$ identity for nucleotide, and 68 to $100 \%$ for amino acid sequences.

The GH gene expression analysis indicated a significant 1.4-fold expression increase for fish exposed to a salinity of $30 \mathrm{~g} \mathrm{l}^{-1}$ for $24 \mathrm{~h}$ (Fig. 1). For fishes analyzed after $3,72 \mathrm{~h}$, and 7 days after transfer, the GH mRNA levels were not significantly different from those of fish kept at the specie's isosmotic point $\left(11 \mathrm{~g} \mathrm{l}^{-1}\right)$. For the GHR gene expression analyses, the obtained results for gills demonstrated a significant 2.8 -fold increase in relation to the control after 7 days at $30 \mathrm{~g} \mathrm{l}^{-1}$ (Fig. 2). Increase of GHR expression in the liver (Fig. 3) was observed earlier than in gills, with a

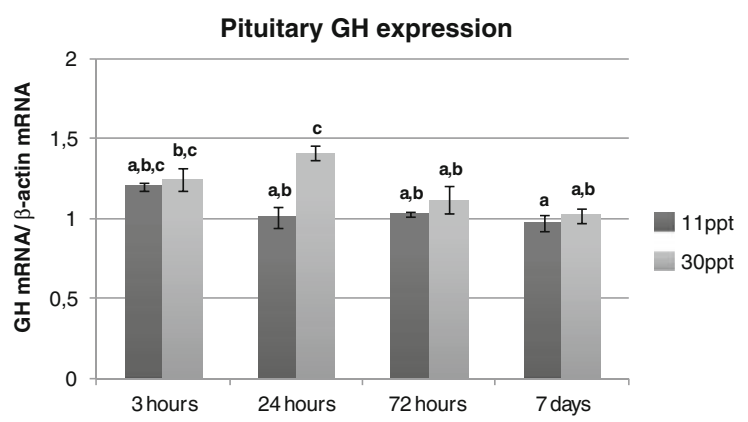

Fig. 1 Time-course growth hormone $(\mathrm{GH})$ gene expression in the pituitary of Paralichthys orbignyanus acclimated to different salinities (11 and $30 \mathrm{~g}^{-1}$ ). The data are showed after normalization by $\beta$-actin gene expression. The different letters indicate significant differences $(P<0.05)$ between treatment groups
Table 2 Identity of obtained nucleotide and amino acid sequences of GH, GHR, IGF-I, and $\beta$-actin genes of $P$. orbignyanus to other flounder species

\begin{tabular}{llll}
\hline Genes & Identity & & Flounder species with maximum identity \\
\hline & Nucleotide & Amino acid & \\
GH & $556 / 573(97 \%)$ & $185 / 190(97 \%)$ & Paralichthys lethostigma \\
GHR & $278 / 362(76 \%)$ & $86 / 125(68 \%)$ & $\begin{array}{l}\text { Hippoglossus hippoglossus } \\
\text { IGF-I }\end{array}$ \\
& $358 / 363(98 \%)$ & $118 / 120(98 \%)$ & $\begin{array}{l}\text { Paralichthys lethostigma } \\
\text { Pactin }\end{array}$ \\
\hline
\end{tabular}




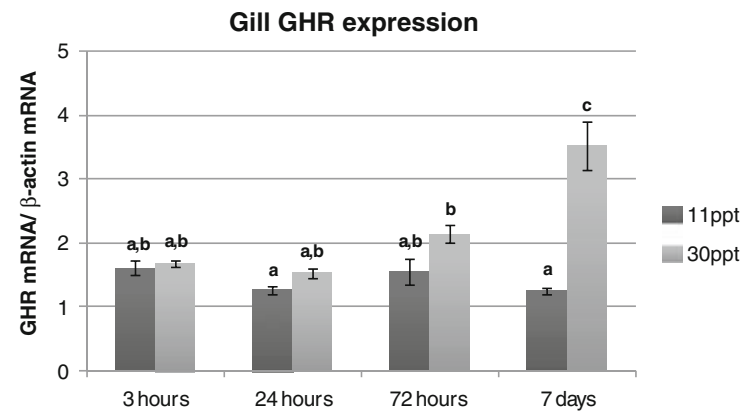

Fig. 2 Time-course growth hormone receptor (GHR) gene expression in the gills of $P$. orbignyanus acclimated to different salinities (11 and $\left.30 \mathrm{~g} \mathrm{l}^{-1}\right)$. The data are showed after normalization by $\beta$-actin gene expression. The different letters indicate significant differences $(P<0.05)$ between treatment groups

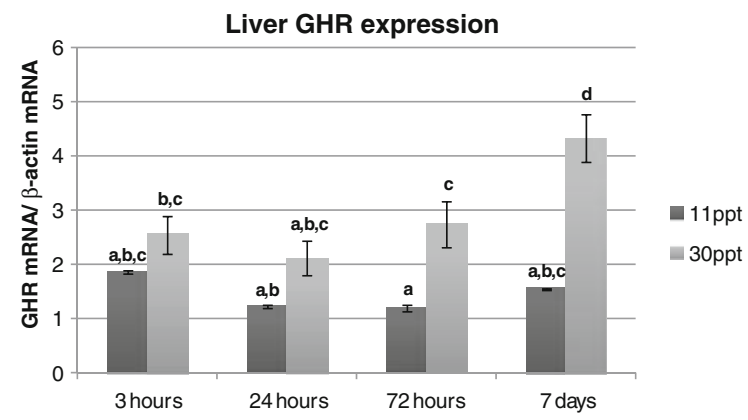

Fig. 3 Time-course GHR gene expression in the liver of $P$. orbignyanus acclimated to different salinities (11 and $30 \mathrm{~g}^{-1}$ ). The data are showed after normalization by $\beta$-actin gene expression. The different letters indicate significant differences $(P<0.05)$ between treatment groups

2.3-fold increase after $72 \mathrm{~h}$, whilst after 7 days expression, it reached 2.8-fold of that observed for the control mRNA levels in fish exposed to $30 \mathrm{~g} \mathrm{l}^{-1}$ for 7 days. For IGF-I gene expression, the results were very similar to GHR in the liver. Figure 4 shows a significant 1.9-fold increase in IGF-I mRNA levels in fish exposed to $30 \mathrm{~g} \mathrm{l}^{-1}$ for $72 \mathrm{~h}$. Similarly to what was observed for GHR, 7 days after transfer, the IGF-I mRNA levels were 2.5 -fold that observed for the controls.

\section{Discussion}

The complete $P$. orbignyanus GH amino acid sequence was deduced from a cDNA sequence highly

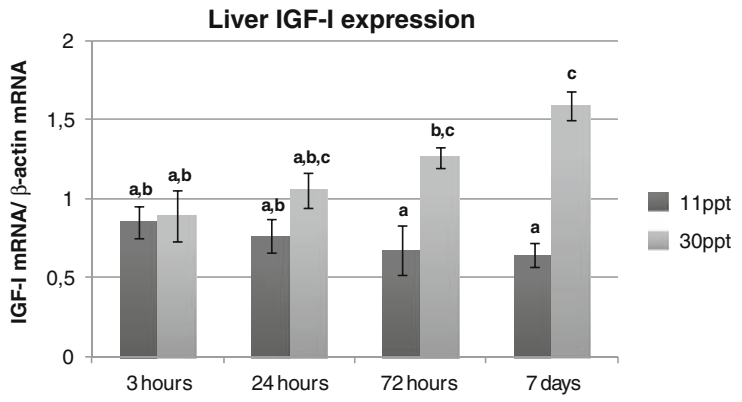

Fig. 4 Time-course insulin-like growth factor I (IGF-I) gene expression in the liver of $P$. orbignyanus acclimated to different salinities (11 and $30 \mathrm{~g}^{-1}$ ). The data are showed after normalization by $\beta$-actin gene expression. The different letters indicate significant differences $(P<0.05)$ between treatment groups

similar to other Pleuronectiformes. The maximum identity was obtained in comparison to Paralichthys lethostigma (97\%, Table 2). The polyadenylation site, signaling peptide and key conserved sites were easily identified by homology to previously described fish $\mathrm{GH}$, adding to the evidence that the described sequence has been correctly identified as the $P$. orbignyanus $\mathrm{GH}$. Interestingly, it was observed a deletion of 14 amino acids near the $\mathrm{C}$-terminus in the Brazilian flounder GH molecule, which is shared by $P$. olivaceus, $P$. lethostigma, and $P$. dentatus (data not shown). It is likely that this deletion has been originated in an evolutionary event that characterizes the Paralichthys genus. Likewise, the GHR, IGF-I, and $\beta$-actin partial sequences obtained have shown high homology to sequences previously described for other flounder species (Table 2).

The results of the gene expression analysis show a higher GH gene expression level in fish transferred to $30 \mathrm{~g}^{-1}$ for $24 \mathrm{~h}$ when compared to the gene expression of fish kept at a salinity corresponding to P. orbignyanus's isosmotic point (Fig. 1). This significant increase in gene expression suggests an osmoregulatory action of the growth hormone immediately after the hyperosmotic shock. Indeed, it has been previously demonstrated that $\mathrm{GH}$ facilitates seawater acclimation, stimulating the proliferation of gill chloride cells, the expression of the $\mathrm{Na}^{+}, \mathrm{K}^{+}$ATPase $\alpha$-subunit, and ion transporters involved in salt secretion (Sakamoto et al. 1993; Björnsson 1997; McCormick 2001; Pelis and McCormick 2001). On the other hand, $72 \mathrm{~h}$ and 7 days after transfer, the levels of GH gene expression were the same as for 
control fish, indicating that the hyperosmotic stress produces a transient increase in the $\mathrm{GH}$ gene expression. In fact, the down-regulation of the $\mathrm{GH}$ gene expression was expected, since pituitary GH secretion is controlled by levels of circulating GH and IGF-I through a negative feedback system, which involves the action of hypothalamic neuropeptides on somatotrophic cells (Pérez-Sánchez 2000). However, if the GH gene expression induced by hyperosmotic stress is transitory because of the negative feedback system, how do we explain the continuous osmoregulatory effect of the hormone? Our findings regarding GHR gene expression levels in gills suggest that osmoregulation in hyperosmotic conditions could be maintained by a synergic action of both GH and IGF-I, but at different times. We observed that liver GHR gene expression increases significantly $72 \mathrm{~h}$ and 7 days after seawater transfer (Fig. 3), with a concomitant increase of IGF-I expression (Fig. 4). On the other hand, gill GHR increases only 7 days after the transference (Fig. 2). These results suggest that IGF-I could act earlier than $\mathrm{GH}$ on gills, since the former is also involved with osmoregulation increasing salinity tolerance and/or gill $\mathrm{Na}^{+}, \mathrm{K}^{+}$-ATPase activity in different fish species (Mancera and McCormick 1998). While we did not analyze the IGF-I receptor in gills, this hypothesis remains to be tested. Thus, the $\mathrm{GH}$ osmoregulatory effect could continue, even after the GH peak induced by the hyperosmotic stress.

Studies performed in salmonids have found the GH level to be temporarily increased after seawater transfer (Boeuf 1993; Björnsson 1997; Björnsson et al. 1998). Additionally, it has been observed that hyperosmotic shock in euryhaline species activates GH gene transcription with a concomitant increase of the growth rate. The increased growth rate associated with the hyperosmotic shock can be considered as a GH collateral effect. In this situation, the primary function of the hormone is to reestablish the osmotic balance, but its presence in the blood also triggers growth through binding with receptors present mainly in liver and muscle cells. However, the same question is raised once more. If the $\mathrm{GH}$ gene expression induced by hyperosmotic stress is transitory, how do we explain the increased growth rate in several fish species exposed to hyperosmotic stress? Once again, one possible answer is that increased growth is sustained not by constantly high levels of circulating
$\mathrm{GH}$, but by an augmented GH sensitivity of tissues involved with IGF-I production, especially liver. If there are more GH receptors in hepatocyte membranes, then the post-receptor signaling system will be more active, even with a lower level of circulating GH. In the present study, we have found a significant increase in liver GHR gene expression that is maintained for $72 \mathrm{~h}$ and 7 days after hyperosmotic stress (Fig. 3). Even though the GH gene expression in the same period was not different from the controls, it seems likely that fish in hyperosmotic conditions could produce more IGF-I and, consequently, improve growth, since they have a higher number of GH receptors in their hepatocyte membranes. Recently, Iwatani et al. (2005) reported faster growth of the sculpin Cottus kazika in seawater than in its native fresh water. In this study, GH and IGF-I gene expression was analyzed in short- $(48 \mathrm{~h})$ and long-term (40 days) experiments. The level of $\mathrm{GH}$ gene transcripts $48 \mathrm{~h}$ after transfer was higher in fish reared in seawater and $1 / 3$ seawater, while no difference was found in IGF-I gene transcripts. Nevertheless, IGF-I gene transcripts increased in seawater-reared fish 40 days after transfer compared with controls, while GH gene transcripts did not. These results corroborate our findings, since we have observed a similar peak of pituitary GH gene expression $24 \mathrm{~h}$ after the hyperosmotic stress and an augmented GHR and IGF-I gene expression in liver $72 \mathrm{~h}$ and 7 days after the transfer of the Brazilian flounder to seawater.

An increased growth rate can be observed only if the energy available for this fish is enough to cope with osmoregulatory costs, leaving a surplus of energy to be used for somatic growth. The energy spared for growth will vary whether the species is euryhaline or stenohaline. In the case of euryhaline species, it has been observed that hyperosmotic shock activates $\mathrm{GH}$ gene transcription and the circulating GH level, which, in turn, increases the growth rate. This has been observed for species such as rainbow trout Oncorhynchus mykiss, brown trout Salmo trutta, sturgeon Acipenser oxyrhynchus, and striped bass Morone saxatilis (Altinok and Grizzle 2001). In regard to stenohaline species, these authors did not observe increased growth rates for goldfish Carassius auratus and channel catfish Ictalurus punctatus acclimatized in brackish water. However, in the channel catfish I. punctatus, Tang et al. (2001) did 
identify an increase in the amount of GH mRNAs in individuals acclimatized in brackish water. In the same way, Drennon et al. (2003), working with the same species, identified a significant increase of plasma GH of fish submitted to the brackish water. These results indicate that, in stenohaline species, GH gene transcription is activated by hyperosmotic shock as well. However, it seems that, in this case, not enough energy would be available for growth, which could be attributed to very high osmoregulation costs in this group of fish.

Most of the flounder species are euryhaline, although in the early development stages, this characteristic is not usually evident. In species such as the southern flounder P. lethostigma (Henne and Watanabe 2003) and summer flounder P. dentatus (Watanabe et al. 1998), growth and survival have been optimal in seawater. However, in turbot (Scophthalmus maximus), the best growth and food conversion were observed in intermediate salinities (Imsland et al. 2003), corroborating the hypothesis of increased growth rate of fish reared near to their isosmotic point (Imsland et al. 2001). In the case of $P$. orbignyanus, Sampaio et al. (2001) did not observe significant differences in the growth performance between fish acclimatized in seawater and brackish water. These studies demonstrate that, in flounder, the growth performance in different salinity conditions can vary widely. However, experimental design in this kind of study seldom includes the strategy of acclimatizing fish in a salinity that corresponds to its isosmotic point, before applying the hyperosmotic shock for growth evaluation. Usually, fish are kept in seawater and afterwards, a group of individuals is transferred to intermediate salinities for growth comparison. In this scenario, the hyperosmotic shock has not been applied and it is likely that GH gene transcription has not been triggered as needed for reestablishing the osmotic balance. Thus, GH levels would probably be kept unchanged in the two groups and any observed differences can be attributed to the energy cost of the osmoregulatory process, which is species-specific and depends on the development stage studied.

Within the context of the results obtained in the present study, we suggest that if fish are appropriately acclimatized at the salinity corresponding to its isosmotic point, and only then submitted to the hyperosmotic shock, the level of GH gene transcription would be immediately increased, since the presence of the hormone is necessary for seawater adaptation. In these conditions, the increased $\mathrm{GH}$ levels triggered by the hyperosmotic shock, even if transitory, would be able to produce a significant effect in the growth performance through augmented IGF-I production. By its turn, augmented IGF-I production could be directly attributed to increased GH tissue sensitivity as a consequence of higher GHR levels, especially in liver and muscle. Recently, Small et al. (2006) stated the relation between GHR and IGF-I in channel catfish, I. punctatus. According to these authors, stress and fasting may induce an increase in hepatic growth hormone resistance through a diminished GHR synthesis, with a consequent lower level of IGF-I production.

In summary, the use of the hyperosmotic shock as a strategy to increase the growth rate of aquaculture species depends basically on the osmoregulatory mechanisms used and the energetic balance, which seems to be species-specific. This observation emphasizes the importance of gene expression studies associated to growth experiments performed in different salinity conditions. The results obtained here reveal that hyperosmotic stress can increase GH gene expression in the flounder $P$. orbignyanus when fish acclimatization is adequately performed. A peak in GH gene expression, even transitory, seems to have increased the $\mathrm{GH}$ sensitivity and, consequently, IGF-I production in liver. Considering these observations, we suggest that the control of salinity acclimatization is likely to be a key parameter in achieving the best growth performance for economically important species.

Acknowledgments This work was supported by Fundação de Amparo a Pesquisa do Estado do Rio Grande do Sul (FAPERGS, Proc. No. 01/1602.5-Brazil), Universidade Federal do Rio Grande (FURG, Brazil) and Programa de Pós-Graduação em Aqüicultura (PPGAq-FURG).

\section{References}

Altinok I, Grizzle JM (2001) Effects of brackish water on growth, feed conversion and energy absorption efficiency by juvenile euryhaline and freshwater stenohaline fishes. $\mathrm{J}$ Fish Biol 59:1142-1152. doi:10.1111/j.1095-8649.2001. tb00181.x

Altschul SF, Madden TL, Schäffer AA, Zhang J, Zhang Z, Miller W, Lipman DJ (1997) Gapped BLAST and PSIBLAST: a new generation of protein database search programs. Nucleic Acids Res 25:3389-3402. doi:10.1093/ nar/25.17.3389 
Bianchini A, Wasielesky W Jr, Miranda Filho KC (1996) Toxicity of nitrogenous compounds to juveniles of flatfish Paralichthys orbignyanus. Bull Environ Contam Toxicol 56:453-459. doi:10.1007/s001289900065

Björnsson BT (1997) The biology of salmon growth hormone: from daylight to dominance. Fish Physiol Biochem 17:924. doi:10.1023/A:1007712413908

Björnsson BT, Stefansson GV, Berhr AI, Hansen T, Stefansson SO (1998) Circulating growth hormone levels in Atlantic salmon smolts following seawater transfer: effects of photoperiod regime, salinity, duration of exposure and season. Aquaculture 168:121-137. doi:10.1016/S00448486(98)00344-5

Boeuf G (1993) Salmonid smolting: a pre-adaptation to the oceanic environment. In: Rankin JC, Jensen FB (eds) Fish ecophysiology. Chapman and Hall, London, pp 105-135

Bolton JP, Collie NL, Kawauchi H, Hirano T (1987) Osmoregulatory actions of growth hormone in rainbow trout (Salmo gairdneri). J Endocrinol 112:63-68

Chelly J, Kaplan JC, Maire P, Gautron S, Kahn A (1988) Transcription of the dystrophin gene in human muscle and non-muscle tissue. Nature 333:858-860. doi:10.1038/333 $858 \mathrm{a} 0$

Drennon K, Moriyama S, Kawauchi H, Small B, Silverstein J, Parhar I, Shepherd B (2003) Development of an enzymelinked immunosorbent assay for the measurement of plasma growth hormone $(\mathrm{GH})$ levels in channel catfish (Ictalurus punctatus): assessment of environmental salinity and GH secretogogues on plasma GH levels. Gen Comp Endocrinol 133:314-322. doi:10.1016/S0016-6480(03)00194-1

Figueiredo JL, Menezes NA (2000) Manual de peixes marinhos do sudeste do Brasil, vol 6. Universidade de São Paulo, Museu de Zoologia

Henne JP, Watanabe WO (2003) Effects of light intensity and salinity on growth, survival, and whole-body osmolality of larval southern flounder Paralichthys lethostigma. J World Aquac Soc 34:450-465. doi:10.1111/j.1749-7345. 2003.tb00084.x

Imsland AK, Foss A, Gunnarsson S, Berntssen MHG, FitzGerald R, Bonga SW, van Ham E, Nævdal G, Stefansson SO (2001) The interaction of temperature and salinity on growth and food conversion in juvenile turbot (Scophthalmus maximus). Aquaculture 198:353-367. doi:10.1016/S0044-8486 (01)00507-5

Imsland AK, Gunnarsson S, Foss A, Stefansson SO (2003) Gill $\mathrm{Na}^{+}, \mathrm{K}^{+}$-ATPase activity, plasma chloride and osmolality in juvenile turbot (Scophthalmus maximus) reared at different temperatures and salinities. Aquaculture 218:671683. doi:10.1016/S0044-8486(02)00423-4

Iwatani H, Inoue K, Takei Y (2005) Expression of insulin-like growth factor I gene is involved in enhanced growth of juvenile four-spine sculpin Cottus kazika in seawater. Fish Sci 71:621-626. doi:10.1111/j.1444-2906.2005.01007.x

Kopchick JJ, Andry JM (2000) Growth hormone (GH), GH receptor, and signal transduction. Mol Genet Metab 71:293-314. doi:10.1006/mgme.2000.3068

Madsen SS, Jensen MK, Nohr J, Kristiansen K (1995) Expression of $\mathrm{Na}^{+}-\mathrm{K}^{+}$-ATPase in the brown trout, Salmo trutta: in vivo modulation by hormones and seawater. Am J Physiol Regul Integr Comp Physiol 269:1339-1345
Mancera JM, McCormick SD (1998) Osmoregulatory actions of the GH/IGF axis in non-salmonid teleosts. Comp Biochem Physiol B 121:43-48. doi:10.1016/S0305-0491 (98)10112-8

McCormick SD (1996) Effects of growth hormone and insulinlike growth factor I on salinity tolerance and gill $\mathrm{Na}^{+}, \mathrm{K}^{+}$ATPase in Atlantic salmon (Salmo salar): interaction with cortisol. Gen Comp Endocrinol 101:3-11. doi:10.1006/ gcen. 1996.0002

McCormick SD (2001) Endocrine control of osmoregulation in teleost fish. Am Zool 41:781-794. doi:10.1668/0003-1569 (2001)041[0781:ECOOIT]2.0.CO;2

Pelis RM, McCormick SD (2001) Effects of growth hormone and cortisol on $\mathrm{Na}^{+}-\mathrm{K}^{+}-2 \mathrm{Cl}^{-}$cotransporter localization and abundance in the gills of Atlantic salmon. Gen Comp Endocrinol 124:134-143. doi:10.1006/gcen.2001.7703

Pérez-Sánchez J (2000) The involvement of growth hormone in growth regulation, energy homeostasis and immune function in the gilthead sea bream (Sparus aurata): a short review. Fish Physiol Biochem 22:135-144. doi:10.1023/ A:1007816015345

Pérez-Sánchez J, Le Bail P-Y (1999) Growth hormone axis as marker of nutritional status and growth performance in fish. Aquaculture 177:117-128. doi:10.1016/S0044-8486 (99)00073-3

Sakamoto T, Hirano T (1993) Expression of insulin-like growth factor I gene in osmoregulatory organs during seawater adaptation of the salmonid fish: possible mode of osmoregulatory action of growth hormone. Proc Natl Acad Sci USA 90:1912-1916. doi:10.1073/pnas.90.5. 1912

Sakamoto T, McCormick SD, Hirano T (1993) Osmoregulatory actions of growth hormone and its mode of action in salmonids: a review. Fish Physiol Biochem 11:155-164. doi:10.1007/BF00004562

Sampaio LA, Bianchini A (2002) Salinity effects on osmoregulation and growth of the euryhaline flounder Paralichthys orbignyanus. J Exp Mar Biol Ecol 269:187196. doi:10.1016/S0022-0981(01)00395-1

Sampaio LA, Bianchini A, Cerqueira VR (2001) Growth of juvenile Brazilian flounder, Paralichthys orbignyanus, cultured at different salinities. J Appl Aquac 11:67-75. doi:10.1300/J028v11n01_06

Sampaio LA, Freitas LS, Okamoto MH, Louzada LR, Rodrigues RV, Robaldo RB (2007) Effects of salinity on Brazilian flounder Paralichthys orbignyanus from fertilization to juvenile settlement. Aquaculture 262:340-346. doi:10.1016/j.aquaculture.2006.09.046

Silveira MPM, Cousin JCB, Haimovici M (1995) Estrutura ovárica e testicular do linguado Paralichthys orbignyanus (Valenciennes, 1839). Atlântica 17:135-152

Small BC, Murdock CA, Waldbieser GC, Peterson BC (2006) Reduction in channel catfish hepatic growth hormone receptor expression in response to food deprivation and exogenous cortisol. Domest Anim Endocrinol 31:340356. doi:10.1016/j.domaniend.2005.12.003

Takeda K, Akira S (2000) STAT family of transcription factors in cytokine-mediated biological responses. Cytokine Growth Factor Rev 11:199-207. doi:10.1016/S1359-6101 (00)00005-8 
Tang Y, Shepherd BS, Nichols AJ, Dunham RA, Chen TT (2001) Influence of environmental salinity on messenger RNA levels of growth hormone, prolactin, and somatolactin in pituitary of the channel catfish (Ictalurus punctatus). Mar Biotechnol (NY) 3:205-217. doi:10. 1007/s101260000061

Thompson JD, Gibson TJ, Plewniak F, Jeanmougin F, Higgins DG (1997) The CLUSTAL_X windows interface: flexible strategies for multiple sequence alignment aided by quality analysis tools. Nucleic Acids Res 25:4876-4882. doi:10.1093/nar/25.24.4876
Wasielesky W, Miranda Filho K, Bianchini A (1995) Tolerância do linguado Paralichthys orbignyanus à salinidade. Braz Arch Biol Technol 38:385-395

Wasielesky W, Bianchini A, Miranda Filho K (1997) Tolerancia a la temperatura de juveniles de lenguado Paralichthys orbignyanus. Frente Maritimo 17A:55-60

Watanabe WO, Feeley MW, Ellis SC, Ellis EP (1998) Light intensity and salinity effects on eggs and yolk sac larvae of the summer flounder. Prog Fish Cult 60:9-19. doi:10. 1577/1548-8640(1998)060<0009:LIASEO > 2.0.CO;2 